\title{
A New Approach to Obtain Cellulose Nanocrystals and Ethanol from Eucalyptus Cellulose Pulp via the Biochemical Pathway
}

\section{Thalita J. Bondancia}

Graduate Program of Chemical Engineering, Federal University of São Carlos, São Carlos, SP 13565-905, Brazil

National Nanotechnology Laboratory for Agribusiness (LNNA), Embrapa Instrumentação, Rua XV de Novembro, 1452, São Carlos, SP 13560-970, Brazil

\section{Luiz Henrique C. Mattoso}

National Nanotechnology Laboratory for Agribusiness (LNNA), Embrapa Instrumentação, Rua XV de Novembro, 1452, São Carlos, SP 13560-970, Brazil

\section{José M. Marconcini}

National Nanotechnology Laboratory for Agribusiness (LNNA), Embrapa Instrumentação, Rua XV de Novembro, 1452, São Carlos, SP 13560-970, Brazil

\section{Cristiane S. Farinas}

Graduate Program of Chemical Engineering, Federal University of São Carlos, São Carlos, SP 13565-905, Brazil

National Nanotechnology Laboratory for Agribusiness (LNNA), Embrapa Instrumentação, Rua XV de Novembro, 1452, São Carlos, SP 13560-970, Brazil

The feasibility of integration of cellulosic ethanol production with the manufacture of cellulose nanofibers (CNF) and cellulose nanocrystals (CNC) was evaluated using eucalyptus cellulose pulp as feedstock and employing the biochemical route alone. For the enzymatic hydrolysis step, experimental central composite design (CCD) methodology was used as a tool to evaluate the effects of solids loading (SL) and enzymatic loading (EL) on glucose release and cellulose conversion. Glucose concentrations from 45 to $125 \mathrm{~g} / \mathrm{L}$ were obtained after $24 \mathrm{~h}$, with cellulose conversions from 35 to 96\%. Validation of the statistical model was performed at SL of $20 \%$ and EL of $10 \mathrm{mg}$ protein/g, which was defined by the desirability function as the optimum condition. The sugars released were used for the production of ethanol by Saccharomyces cerevisiae, resulting in $62.1 \mathrm{~g} / \mathrm{L}$ ethanol after $8 \mathrm{~h}$ (yield of 95.5\%). For all the CCD experimental conditions, the residual solids presented CNF characteristics. Moreover, the use of a new strategy with temperature reduction from 50 to $35^{\circ} \mathrm{C}$ after $24 \mathrm{~h}$ of enzymatic hydrolysis enabled CNC to be obtained after $144 \mathrm{~h}$. The CNC showed a crystallinity index of $83 \%$, length of $260 \mathrm{~nm}$, diameter of $15 \mathrm{~nm}$, and aspect ratio $(L / D)$ of 15. These characteristics are suitable for many applications, such as reinforcement in polymeric materials and other lower volume higher value bio-based products. The findings indicate the viability of obtaining ethanol and CNC using the biochemical route exclusively, potentially contributing to the future implementation of forest biorefineries. (C) 2017 American Institute of Chemical Engineers Biotechnol. Prog., 33:1085-1095, 2017

Keywords: cellulose nanocrystal, cellulosic ethanol, enzymatic hydrolysis, biorefinery, renewable biomass

\section{Introduction}

The biorefinery concept has been identified as one of the most promising routes to build the new industries of the future, as it allows the use of renewable biomass such as lignocellulosic residues for the production of biofuels including cellulosic ethanol, together with other chemicals and

Additional Supporting Information may be found in the online version of this article.

Correspondence concerning this article should be addressed to C. S. Farinas at cristiane.farinas@embrapa.br. bioproducts. $^{1-4}$ Among these bioproducts, high added-value materials such as nanocellulose can significantly contribute to the economic viability of the overall process. ${ }^{5,6}$ Recent studies have proposed the application of the biorefinery concept to the forestry sector, with the aim of diversifying the paper and pulp industry and expanding the product portfolio. ${ }^{5,7-10}$ Such novel products could contribute to the expansion of the paper and pulp industry into new and diversified markets, generating additional income and providing an important strategy to cope with market and economic fluctuations. However, selection of the most appropriate technology 
and the best target products for successful implementation of the biorefinery concept in the pulp and paper sector can present a great challenge from both the technical-economic and environmental sustainability standpoints. The development of green technologies for the implementation of biorefineries needs to be addressed in the switch to a sustainable bio-based economy. ${ }^{2}$

Among the possible technological routes for the conversion of lignocellulosic biomass in biorefineries, the biochemical pathway, which involves enzymatic catalysis and microbial fermentation, is one of the most promising green and sustainable routes, due to the milder operating conditions and high conversion efficiency. Therefore, the biochemical pathway using biocatalysts for the manufacture of a diversity of products is highly advantageous both technically and environmentally, and is compatible with the demands of the bio-economy, ${ }^{4,11-13}$ However, the conversion of biomass into simple sugars via the biochemical route results in high amounts of a residual solid fraction, due to the high recalcitrance of lignocellulosic materials. ${ }^{14-17}$ The residues from the enzymatic hydrolysis step contain highly crystalline cellulose, because the enzymes degrade the amorphous part of the cellulose at a much faster rate than the crystalline fraction. ${ }^{18}$ A potential use of this solid residue is for the production of nanocellulose, which is a high-value material that can be obtained in the form of cellulose nanofibers $(\mathrm{CNF})$ or cellulose nanocrystals $(\mathrm{CNC})$. Highly organized $\mathrm{CNC}$ can be used to improve the strength and mechanical properties of various materials. ${ }^{6,19,20}$ Due to their mechanical and optical properties, $\mathrm{CNC}$ have attracted interest for use in biomedicine, ${ }^{21}$ packaging, ${ }^{22}$ and mechanical reinforcement of matrices, ${ }^{23}$ enzyme immobilization, ${ }^{24}$ among other applications. $^{25}$ The conventional method used to obtain CNC employs acid hydrolysis reactions that require high concentrations of strong acids such as sulfuric acid or hydrochloric acid, which react rapidly with amorphous cellulose, with interruption of the reaction before the hydrolysis of crystalline cellulose. ${ }^{26,27}$ In contrast, the use of enzymatic reactions to hydrolyze the biomass to obtain nanocellulose usually results in solid materials with characteristics of $\mathrm{CNF}^{28}$ Therefore, it still remains a challenge to obtain $\mathrm{CNC}$ from biomass using only the biochemical pathway of enzymatic reactions.

Recent research concerning the integration of cellulosic ethanol and nanocellulose production processes has demonstrated the potential of this approach applied to different lignocellulosic feedstocks. ${ }^{28-35}$ However, to ensure the economic viability of this integrated process, it is necessary to identify the optimum operational conditions, considering the solids loading (SL) and enzyme loading used in the enzymatic hydrolysis step to produce nanocellulose together with sugar at a concentration high enough for ethanol production. The processing of biomass at high SL leads to a higher sugar concentration, improved ethanol productivity, and reduced capital costs due to lower energy inputs. ${ }^{14,36,37}$ Nevertheless, working at a high SL (above $15 \% \mathrm{w} / \mathrm{v}$ ) introduces many technical challenges. ${ }^{14}$ The higher solids content results in a reduced enzymatic hydrolysis yield, due to limitations caused by factors such as poorer mass transfer, ${ }^{14,37-39}$ end-products inhibition, ${ }^{40,41}$ nonproductive enzyme adsorption into lignin, ${ }^{37,42}$ and mixing difficulties caused by the high initial viscosity. ${ }^{43}$ On top of that, there is a need to minimize the enzyme loading applied in the hydrolysis step, because the high cost of the enzymatic cocktail required for biomass saccharification has a significant impact on the economics of the overall process. ${ }^{44,45} \mathrm{Up}$ to now, studies addressing the integration of nanocellulose and ethanol production using the enzymatic route have employed a relatively low solids concentration and/or additional mechanical steps. ${ }^{46-48}$ Given the current demand for industrial processes to use high SLs in the enzymatic hydrolysis step, ${ }^{14}$ there is a need for bioprocess engineering studies focusing on optimization of the operational variables for viable integrated nanocellulose and ethanol production using a green and sustainable route. Furthermore, to the best of our knowledge, there have been no studies concerning the development of a bioprocess to obtain CNC from biomass using exclusively the enzymatic route. The coproduction of CNC in addition to ethanol in such an integrated bioprocess can contribute to a higher return of investment than with the production of biofuels alone.

This study investigates the feasibility of integrating the production of cellulosic ethanol and nanocellulose using exclusively the biochemical route. To this end, experimental central composite design (CCD) methodology was used as an optimization tool in the enzymatic hydrolysis step, with evaluation of the effects of solids loading (SL) and enzymatic loading (EL) on the glucose released and cellulose conversion, to achieve conditions similar to those used in industry. The feasibility of cellulosic ethanol production was evaluated for the optimized operational condition selected by applying a procedure that used the desirability function for simultaneous optimization of the multiple responses (sugar release and cellulose conversion). The physical, chemical, and morphological properties of the residual solids obtained were characterized by XRD, STEM, Fourier transform infrared spectroscopy (FTIR), and thermal TGA analyses. In addition, a novel strategy is proposed for obtaining CNC using enzymes alone, involving extending the reaction time and reducing the temperature.

\section{Experimental}

\section{Materials}

A bleached kraft eucalyptus pulp was donated by the Suzano Pulp and Paper Company (Brazil). The pulp was reduced to a particle size smaller than $2 \mathrm{~mm}$ using a knife mill. The chemical composition of the eucalyptus pulp was $75.6 \% \pm 2.3 \%$ cellulose, $14.6 \% \pm 0.6 \%$ hemicellulose, $6.7 \% \pm 1.2 \%$ lignin, and $1.1 \% \pm 0.2 \%$ ash, determined according to the methodology of NREL. ${ }^{49}$ The commercial enzyme preparation Cellic CTec3 (206 FPU/g, $122 \mathrm{mg}$ protein/g) was obtained from Novozymes (Bagsvaerd, Denmark). The filter paper activity of the enzymatic preparation was determined according to Ghose, ${ }^{50}$ and the protein content was determined by the Bradford protocol. ${ }^{51}$

\section{Enzymatic hydrolysis}

Enzymatic hydrolysis was carried out in $200 \mathrm{~mL}$ Erlenmeyer flasks containing $10 \mathrm{~g}$ of eucalyptus pulp and sodium citrate buffer $(0.1 \mathrm{M}, \mathrm{pH} 5)$, at $50^{\circ} \mathrm{C}$, in an incubator/shaker at $200 \mathrm{rpm}$. The volume of buffer ranged from 68 to $125 \mathrm{~mL}$, according to the solids content, as shown in Table 1. The enzymatic dosages were also varied (Table 1$)$. The glucose concentration and cellulose conversion were determined during the course of the reaction (at $0,6,12,24$, and $30 \mathrm{~h}$ ). Quantification of glucose was performed using a GOD-POD enzymatic kit (Doles, Brazil).

\section{Experimental design methodology}

The enzymatic hydrolysis experimental conditions were selected using a full factorial CCD that included 11 runs, 
Table 1. Experimental Conditions and Responses of the Statistical Experimental Design for Glucose Concentration and Cellulose Conversion After the Enzymatic Hydrolysis of Eucalyptus Pulp for $24 \mathrm{~h}$ at $50^{\circ} \mathrm{C}$ Under Different Solids and Enzyme Loadings

\begin{tabular}{lccrc}
\hline TTrial & Solids loading $(\%)$ & Enzyme loading $(\mathrm{mg}$ protein/g) & Glucose $(\mathrm{g} / \mathrm{L})$ & Cellulose conversion $(\%)$ \\
\hline 1 & $10(-1)$ & $5(-1)$ & 50.7 & 57.2 \\
2 & $20(1)$ & $5(-1)$ & 89.1 & 52.8 \\
3 & $10(-1)$ & $15(1)$ & 67.4 & 82.3 \\
4 & $20(1)$ & $15(1)$ & 125.4 & 68.8 \\
5 & $8(-1.41)$ & $10(0)$ & 107.7 & 96.5 \\
6 & $22(1.41)$ & $10(0)$ & 44.8 & 35.3 \\
7 & $15(0)$ & $3(-1.41)$ & 103.4 & 74.5 \\
8 & $15(0)$ & $17(1.41)$ & 97.6 & 74.6 \\
9 & $15(0)$ & $10(0)$ & 94.0 & 74.5 \\
10 & $15(0)$ & $10(0)$ & 94.2 & 74.6
\end{tabular}

corresponding to four factorial points, four axial points, and three central points. The factors and levels are shown in Table 1. Response surface analysis was used to evaluate the effects of solids loading (SL) and enzyme loading (EL) in the hydrolysis reaction in terms of glucose concentration $(\mathrm{g} /$ L) and cellulose conversion (\%). The data were analyzed using ANOVA (analysis of variance) at a significance level of $95 \%(P=0.05)$ and response surface plots were constructed using Statistica ${ }^{\circledR} 10$ software.

The simultaneous optimization of the multiple responses (sugar release and cellulose conversion) was evaluated using the desirability function. ${ }^{52}$ This methodology consists of first converting each response, $y_{i}$, into an individual desirability function that varies over the range $0 \leq \mathrm{d}_{\mathrm{i}} \leq 1$. If $\mathrm{y}_{\mathrm{i}}$ is at its target, then $d_{i}=1$, and if the response is outside an acceptable region, $d_{i}=0$. The design variables are then chosen to maximize the overall desirability, $D=\left(\mathrm{d}_{1}, \mathrm{~d}_{2}, \mathrm{~d}_{3}, \ldots, \mathrm{d}_{\mathrm{m}}\right)^{1 / \mathrm{m}}$. Desirability response surface plots were constructed using the Statistica ${ }^{\circledR} 10$ software.

\section{Production of ethanol}

Alcoholic fermentations were conducted according to the methodology described by Sonego et al. ${ }^{53}$ Ethanol fermentation was carried out in $125 \mathrm{~mL}$ Erlenmeyer flasks with $30 \mathrm{~mL}$ of hydrolysates, using the commercial yeast Saccharomyces cerevisiae (Fleischmann) at an initial concentration of $25 \mathrm{~g} \mathrm{~L}^{-1}$ (dry basis). The glucose $\left(134 \mathrm{~g} \mathrm{~L}^{-1}\right)$ obtained using the selected operational condition (SL of $20 \%$ and EL of $10 \mathrm{mg}$ protein/g, with fermentation for $72 \mathrm{~h}$ ) was mixed with $5.6 \mathrm{~g} \mathrm{~L}^{-1} \mathrm{KH}_{2} \mathrm{PO}_{4}, 1.4 \mathrm{~g} \mathrm{~L} \mathrm{~L}^{-1}$ $\mathrm{MgSO}_{4} \cdot 7 \mathrm{H}_{2} \mathrm{O}$, $6.8 \mathrm{~g} \mathrm{~L}^{-1}$ yeast extract, and $5.32 \mathrm{~g} \mathrm{~L}^{-1}$ urea. The initial $\mathrm{pH}$ of the fermentation broth was adjusted to 4.6, and it was maintained during the course of the fermentation. The yeast was acclimatized during $15 \mathrm{~min}$ and the fermentation was performed for $10 \mathrm{~h}$ at $34^{\circ} \mathrm{C}$, with agitation at $250 \mathrm{rpm}$. Samples were withdrawn every $2 \mathrm{~h}$ for analyses of ethanol production and glucose consumption. The concentrations of glucose and ethanol were determined by HPLC, using a Shimadzu instrument equipped with a refractive index detector maintained at $40^{\circ} \mathrm{C}$ and a Shodex $\mathrm{KS}-802$ column maintained at $80^{\circ} \mathrm{C}$. The mobile phase was Milli-Q water at a flow rate of $1 \mathrm{~mL} \mathrm{~min}^{-1}$. The ethanol yield factor (Y) (Eq. (1)) was used to calculate the ethanol yield, described by Eq. (2) (\% of theoretical yield), and the volumetric ethanol productivity $\left(\mathrm{Q}\right.$, in units of $\mathrm{g} / \mathrm{L} \mathrm{h}^{-1}$ ) was calculated using Eq. (3). In Eq. (2), the value 0.511 is the theoretical yield factor for the alcoholic fermentation process.

$$
\begin{gathered}
Y=\frac{C_{\text {ethanol }}^{8 h}-C_{\text {ethanol }}^{0 h}}{C_{\text {glucose }}^{0 h}-C_{\text {glucose }}^{8 h}} \\
E_{y}=\left(\frac{Y}{0.511}\right) * 100 \\
Q=\frac{C_{\text {ethanol }}^{8 h}-C_{\text {ethanol }}^{0 h}}{8 h-0 h}
\end{gathered}
$$

\section{Strategy to obtain CNC}

A strategy was developed to obtain CNC directly from the enzymatic hydrolysis reactions of the eucalyptus pulp, based on extending the reaction time to up to $144 \mathrm{~h}$ and reducing the temperature from $50^{\circ} \mathrm{C}$ to 35 and $40^{\circ} \mathrm{C}$. The selected operational condition (SL of $20 \%$ and EL of $10 \mathrm{mg}$ protein/g) was used, and samples were withdrawn at $24 \mathrm{~h}$ intervals up to $144 \mathrm{~h}$ of reaction. The glucose concentration and crystallinity index $(\%)$ were measured during the course of the reaction.

\section{$X$-ray diffraction}

The crystallinity index (CI) was determined by XRD using a Shimadzu Model 6000 X-ray diffractometer with $\mathrm{Cu} \mathrm{K} \alpha$ radiation (wavelength $=1.5406 \AA$ ), operated at $30 \mathrm{kV}$ and $30 \mathrm{~mA}$. Scattered radiation was detected in the $2 \theta$ range $5^{\circ}$ $40^{\circ}$, at a scan rate of $2^{\circ} / \mathrm{min}$. The CI percentage was calculated using Eq. (4), where $I_{200}$ is the height of the 200 peak $\left(2 \theta=22.5^{\circ}\right)$ and $I_{a m}$ is the minimum intensity between the 200 and 110 peaks $\left(2 \theta=18^{\circ}\right) . I_{200}$ represents both crystalline and amorphous components, while $I_{a m}$ represents the amorphous component. ${ }^{54}$

$$
C I(\%)=\left(1-\frac{I_{a m}}{I_{200}}\right) \times 100
$$

\section{Field emission scanning electron microscopy}

The CNF samples were examined by field emission scanning electron microscopy (FEG-SEM) using a JEOL Model JSM-607 $1 \mathrm{~F}$ microscope operated at $2.0 \mathrm{kV}$ and $1.0 \mathrm{~nm}$ resolution. A droplet of diluted suspension containing CNF obtained by enzymatic hydrolysis for between 24 and $144 \mathrm{~h}$ (using SL of $20 \%$ and EL of $10 \mathrm{mg}$ protein/g) was deposited on a silicon plate and mounted onto an aluminum stub using silver epoxy.

\section{Scanning transmission electron microscopy}

The morphology of the CNC obtained at $144 \mathrm{~h}$ using the optimized condition (SL of $20 \%$ and EL of $10 \mathrm{mg}$ protein/g) 
was evaluated by STEM, using a Tecnai G2 F20 microscope (FEI, Hillsboro, OR). The images were acquired with a bright-field (BF) detector. A drop of diluted CNC suspension was deposited on a 400-mesh carbon- $\mathrm{Cu}$ grid and allowed to dry. The grid was stained with $1.5 \%$ uranyl acetate aqueous solution and dried at room temperature. The $\mathrm{CNC}$ diameter and length were measured using Image Pro-Plus software, with around 100 measurements for each sample. The dimensions presented here refer to the average of these 100 individual measurements, which values were estimated using the digital image processing tools that allow quantitative measurements of both CNC diameter and length.

\section{FTIR analysis}

Fourier transform infrared spectroscopy was used to characterize the chemical compositions of the original bleached kraft eucalyptus pulp and the resulting nanocellulose materials. A Bruker Vertex 70 instrument fitted with a diamond crystal was operated in ATR mode in the frequency range $4000-400 \mathrm{~cm}^{-1}$, with resolution of $4 \mathrm{~cm}^{-1}$ and 32 scans.

\section{Thermogravimetric analysis}

Themogravimetric and derivative thermogravimetry (DTG) analyses of the original bleached kraft eucalyptus pulp and the samples obtained after the enzymatic hydrolysis were performed using a TA Instruments Model TGA Q500 V6.3 analyzer. The samples $(\sim 5 \mathrm{mg})$ were heated in a platinum crucible from ambient temperature $\left(25^{\circ} \mathrm{C}\right)$ to $650^{\circ} \mathrm{C}$, at a heating rate of $10^{\circ} \mathrm{C} \min ^{-1}$, under an air atmosphere $\left(60 \mathrm{~mL} \mathrm{~min}^{-1}\right)$.

\section{RESULTS AND DISCUSSION}

\section{Temporal profile of the enzymatic hydrolysis reaction of eucalyptus cellulose pulp}

The enzymatic hydrolysis reactions of the eucalyptus cellulose pulp under the different experimental conditions of solids loading (SL) and enzyme loading (EL) (Table 1) were monitored over a total period of $30 \mathrm{~h}$. Figure 1 shows a representative temporal profile of both glucose release and cellulose conversion obtained by using $15 \%$ of SL and $10 \mathrm{mg}$ protein/g of EL (central point of the CCD). Except for the magnitude of the glucose concentration and cellulose conversion values, a similar profile was observed when using SL ranging from 8 to $22 \%(\mathrm{w} / \mathrm{w})$ and $\mathrm{EL}$ ranging from 3 to $17 \mathrm{mg}$ protein $/ \mathrm{g}$. The glucose concentration varied from approximately 45 up to $125 \mathrm{~g} / \mathrm{L}$ after $24 \mathrm{~h}$ of hydrolysis (Table 1), with a plateau reached after this period for most of the conditions. Hence, it was possible to obtain conditions in which the glucose release exceeded $100 \mathrm{~g} / \mathrm{L}$, which is the sugar level recommended to be achieved to ensure an efficient distillation favorable to the economics of ethanol production. ${ }^{55}$ For the range of experimental conditions described in Table 1, the cellulose conversion yields varied from 35 to $96 \%$ after $24 \mathrm{~h}$. For most of the different experimental conditions evaluated, no significant improvements in cellulose conversion were observed after $24 \mathrm{~h}$ of reaction. Therefore, this reaction time $(24 \mathrm{~h})$ was selected in the subsequent optimization studies employing statistical tools.

The enzymatic hydrolysis reaction usually requires a time of between 24 and $96 \mathrm{~h}$ to achieve reasonable cellulose conversion and its performance depends on many factors,

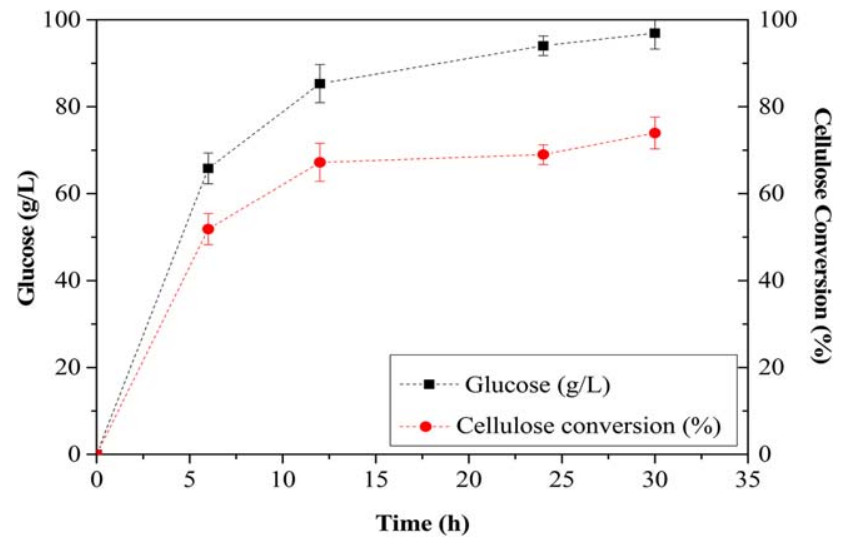

Figure 1. Glucose concentration (g/L) (black square) and cellulose conversion $(\%)$ (red circle) for the hydrolysis of eucalyptus pulp using solids loadings $15 \%(\mathrm{w} / \mathrm{v})$ and enzyme loadings of $10 \mathrm{mg}$ protein $/ \mathrm{g}$, at $50^{\circ} \mathrm{C}, \mathrm{pH} 5$, and $250 \mathrm{rpm}$.

including the type of enzyme cocktail used, the enzyme loading, the type of lignocellulosic biomass, the SL, and the process operational conditions. ${ }^{36,56,57}$ A shorter reaction time is advantageous in terms of energy consumption; in this work, the proposed technique is based on the hypothesis that the amorphous fraction of the cellulose is hydrolyzed at a much faster rate than the crystalline fraction, ${ }^{18}$ which usually remains as a residual solid after the saccharification step in the $2 \mathrm{G}$ ethanol production process. In the present case, it was not desirable for the proposed integrated process to allow the complete conversion of cellulose, justifying selection of a $24 \mathrm{~h}$ reaction time to evaluate the effects of the operational variables on hydrolysis performance.

\section{Optimization of the enzymatic hydrolysis reaction using experimental design methodology}

After selection of a reaction time of $24 \mathrm{~h}$ for enzymatic hydrolysis of the eucalyptus pulp, the effects of solids loading (SL) and enzyme loading (EL) on glucose release and cellulose conversion were evaluated using statistical experimental design methodology. Table 1 presents the experimental conditions employed and the responses of the CCD. The purpose of this part of the study was to find a process operational condition that resulted in a high glucose concentration $(>100 \mathrm{~g} / \mathrm{L})$ together with a residual solid material that could be used for the production of nanocellulose. In addition, it was also important to reduce the enzyme loading to the minimum possible, since enzymes are expensive and influence the overall economics of the process. ${ }^{44,45}$ As can be seen in Table 1, the conditions employing both a high solids content and a high enzyme loading generally resulted in higher glucose concentration values, while a lower solids content resulted in improved cellulose conversion. Glucose concentrations of up to $125 \mathrm{~g} / \mathrm{L}$ were achieved using SL of $20 \%$ and EL of $15 \mathrm{mg} / \mathrm{g}$, while at lower solids contents $(8-10 \%)$, cellulose conversion of up to $96 \%$ was obtained. An explanation for this is that the increase in solids content and enzyme loading favored the hydrolysis and sugar release up to a certain point, at which mixing and mass transfer limitations became significant. ${ }^{43}$ Conversely, high conversion of cellulose is usually achieved using a low loading of solids. ${ }^{58}$

To identify the best relationship between the two response variables, investigation was made of the effects of SL and 
EL on glucose concentration and cellulose conversion, together with determination of the coefficients of the mathematical model and statistical parameters (Table S1). The statistical analyses considered the $95 \%$ confidence limit $(P<0.05)$. In the case of the glucose concentration, statistically significant effects were found for the linear and quadratic terms of the enzyme loading, as well as the quadratic term of the SL. The cellulose conversion showed statistically significant effects for all the parameters, with the exception of the quadratic term of the SL. The solids and enzyme loadings showed positive effects on the glucose concentration, indicating that an increase in one of these variables would contribute to increased glucose release. The cellulose conversion showed a positive effect of enzyme loading, indicating that a higher enzyme loading facilitated the conversion. However, there was a negative effect of SL on cellulose conversion, indicating that an increase of this variable decreased cellulose conversion.

The ANOVA analysis resulted in correlation coefficients $(R)$ of $95 \%$ for glucose concentration and $88 \%$ for cellulose conversion, with $F$-test values $\left(F_{\text {measured }} / F_{\text {critical }}\right)$ of 11.38 and 4.70 , respectively. These values were very satisfactory for obtaining the predictive models used to describe the response surface plots for glucose concentration (Figure 2a) and cellulose conversion (Figure $2 b$ ) as a function of SL and EL. The models could be described by Eqs. 5 and 6, respectively:

$$
\text { Glucose }(\mathrm{g} / \mathrm{L})=90.37+18.80 * \mathrm{SL}+17.74 * \mathrm{EL}-7.34 * \mathrm{EL}^{2}
$$

Cellulose conversion $(\%)=74.14-9.51 * \mathrm{SL}+12.05 * \mathrm{EL}-9.31 * \mathrm{EL}^{2}$

The statistical analysis revealed that glucose concentrations above $100 \mathrm{~g} / \mathrm{L}$ could be achieved using solids and enzyme loadings at levels corresponding to the experimental conditions above the central point values (Figure 2a). However, a better analysis of the performance efficiency of the hydrolysis reaction requires evaluation of the glucose concentration in conjunction with the cellulose conversion values. $^{18}$ It can be seen that cellulose conversion values exceeding $60 \%$ could be obtained using SLs between 10 and $15 \%$ and enzyme loadings from 10 to $15 \mathrm{mg} / \mathrm{g}$ (Figure $2 \mathrm{~b}$ ).

Since the main aim of this work was to achieve an operational condition (considering SL and EL) suitable for the integrated production of nanocellulose and cellulosic ethanol, a simultaneous analysis was made of the two response surface plots presented in Figure 2, establishing a minimum acceptable threshold for each variable. For the ethanol production process, the criterion chosen was a minimum acceptable glucose concentration of $100 \mathrm{~g} / \mathrm{L}$. For nanocellulose production, the minimum acceptable cellulose conversion was set at $50 \%$, so that after the reaction there would be sufficient solids remaining to obtain nanocellulose. The simultaneous optimization of both response variables (glucose concentration and cellulose conversion) was carried out by means of the procedure employing the desirability function. ${ }^{59}$

The response surface obtained in the simultaneous optimization of both responses for the desired integration process is shown in Figure 3. In the procedure using the desirability function method, the coded values 0.0 (undesirable), 0.5 (somewhat desirable), and 1.0 (highly desirable) were used. $^{52}$ Desirability of 1.0 (the target value) was used to
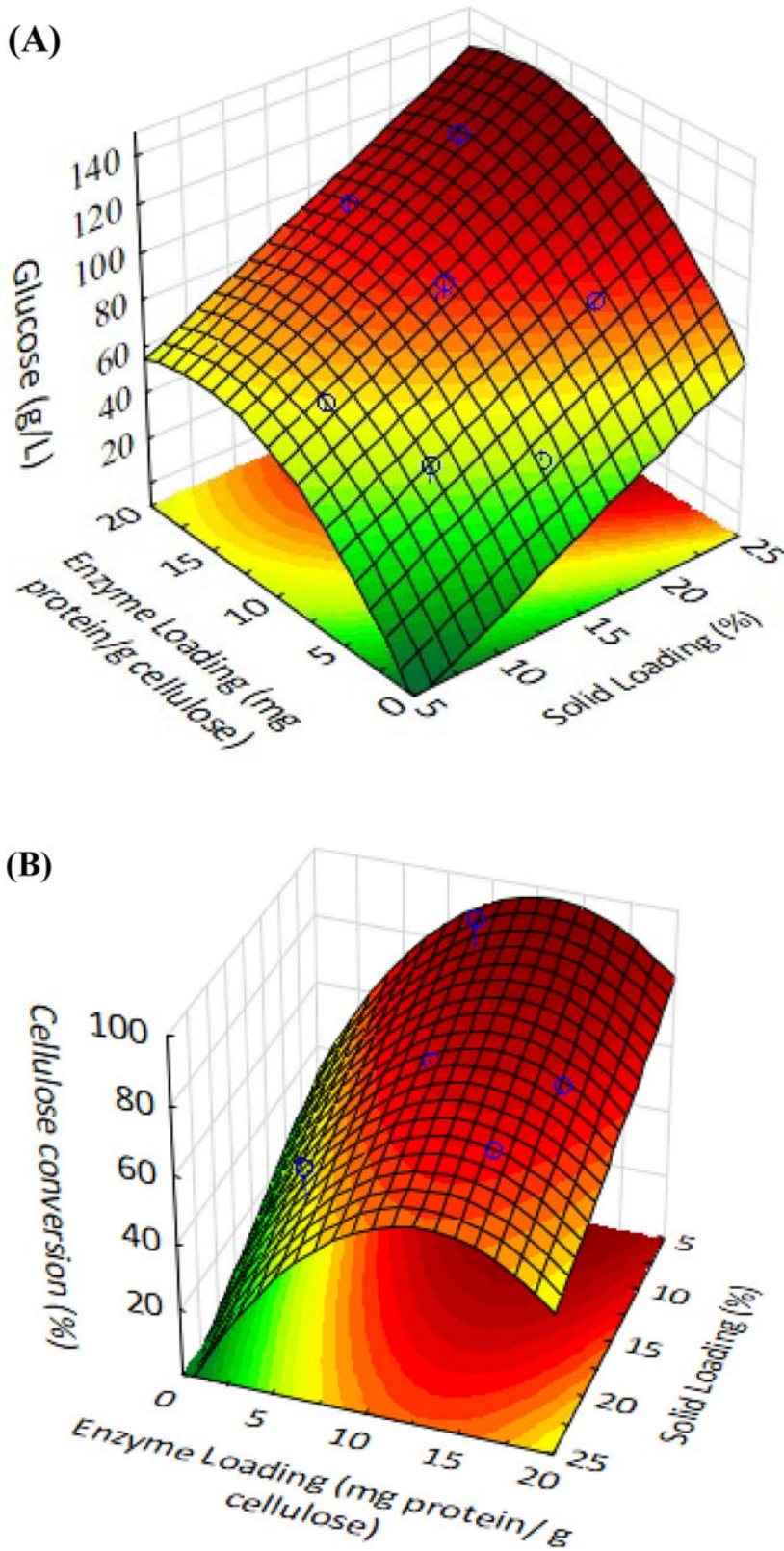

Figure 2. Response surface for the CCD experimental design showing the influence of solids loading $(\%)$ and enzyme loading $(\mathrm{mg}$ protein/g) in the hydrolysis of eucalyptus pulp for $24 \mathrm{~h}$.

Conditions: $50^{\circ} \mathrm{C}, \mathrm{pH} 5,250 \mathrm{rpm}$. (a) Glucose concentration $(\mathrm{g} / \mathrm{L})$; (b) cellulose conversion $(\%)$.

obtain the optimum operational condition of the overall integration process (Figure 3 ). The desirability function simulation revealed that the optimum values ranged from 17.5 to $22.5 \%$ for SL and from 10 to $20 \mathrm{mg} / \mathrm{g}$ for enzyme loading, with $D=0.94$, indicating that the overall process was within the optimal condition established.

Validation of the statistical models obtained for the simultaneous optimization was carried out at a SL of $20 \%$ and enzyme loading of $10 \mathrm{mg}$ protein/g. These SL and EL values were within the optimal values of the desirability function and were compatible with finding a condition of high SL and low enzyme loading that resulted in high glucose levels and efficient cellulose conversion. The values predicted by the statistical models described by Eqs. 5 and 6 (109.2 g/L for glucose concentration and $63.2 \%$ for cellulose 


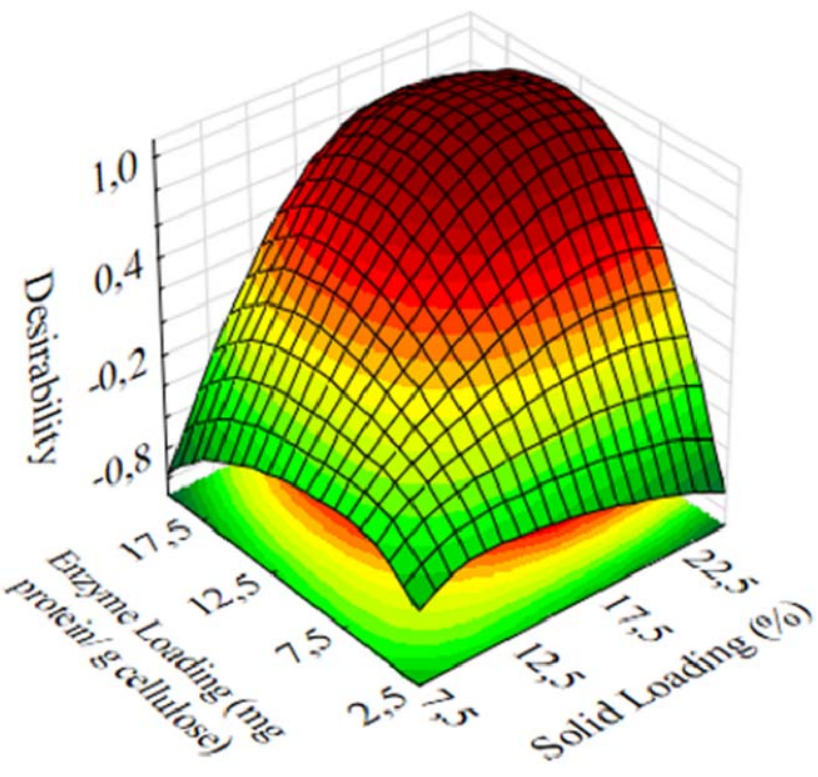

Figure 3. Response surface for the desirability function showing the optimal limits of solids loading (\%) and enzyme loading ( $\mathrm{mg}$ protein/g) in the hydrolysis of eucalyptus pulp for the simultaneous optimization of glucose release and cellulose conversion.

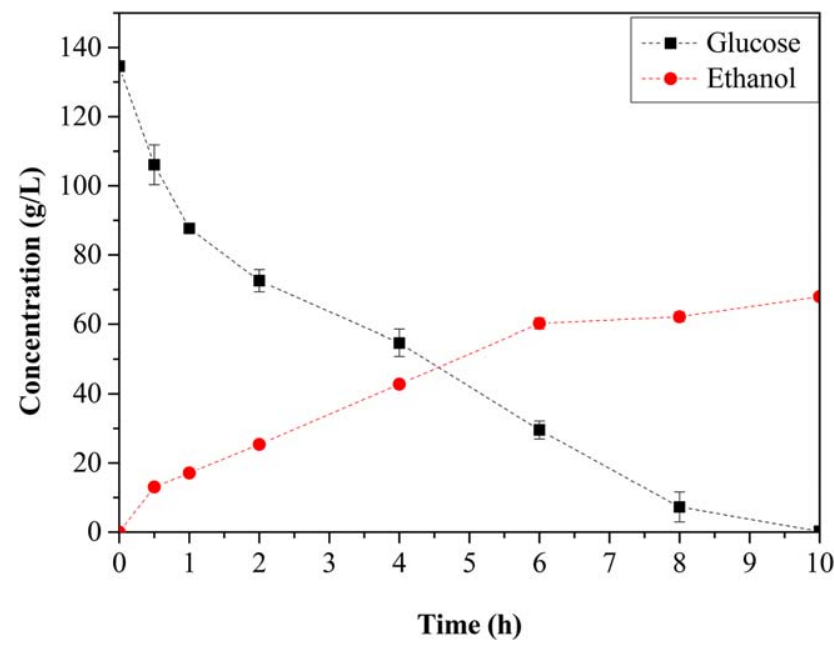

Figure 4. Profile of glucose consumption (squares) and ethanol production (circles) during alcoholic fermentation by Saccharomyces cerevisiae of the glucose released under the optimized condition of $20 \%$ solids loading and $10(\mathrm{mg}$ protein/g) enzyme loading.

conversion) were very close to the glucose concentration $(108.9 \pm 1.8 \mathrm{~g} / \mathrm{L})$ and cellulose conversion values $(63.3 \pm$ $0.5 \%$ ) obtained experimentally. Hence, the enzymatic hydrolysis of eucalyptus pulp under an operational condition with SL of $20 \%$ and enzyme loading of $10 \mathrm{mg}$ protein/g resulted in glucose release exceeding $100 \mathrm{~g} / \mathrm{L}$, which would be suitable for the production of ethanol. Furthermore, the cellulose was only partially converted $(63 \%)$, so there would be potential to use the residual solids fraction to obtain a product with high added value, such as nanocellulose.

\section{Ethanol production}

The alcoholic fermentation was carried out using the sugars released under the previously selected hydrolysis condition of $20 \% \mathrm{SL}$ and $10 \mathrm{mg}$ protein/g enzyme loading, with

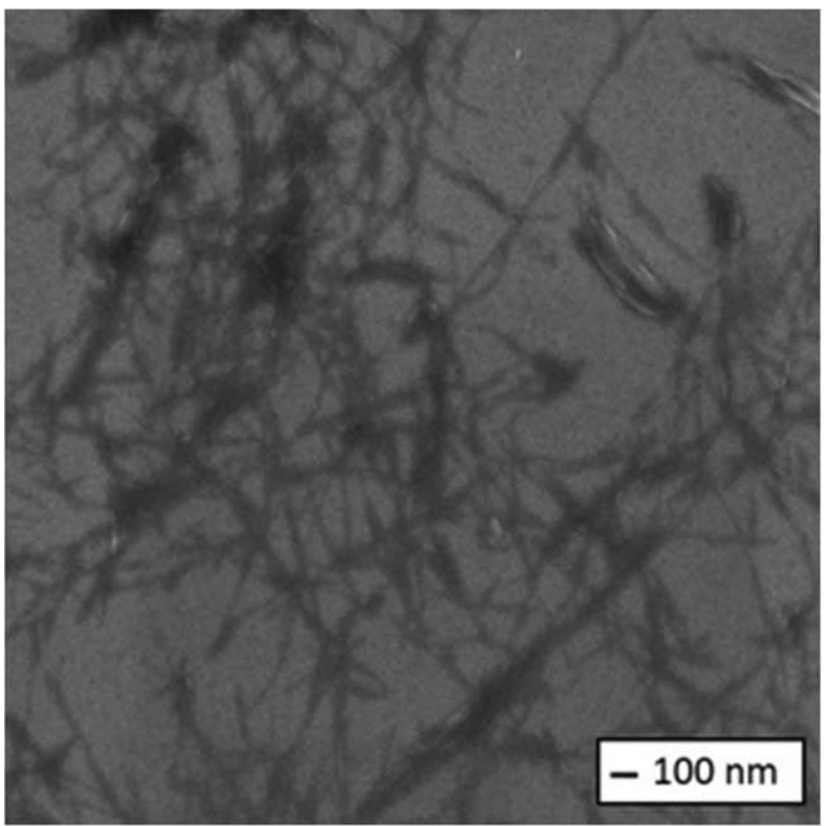

(a)

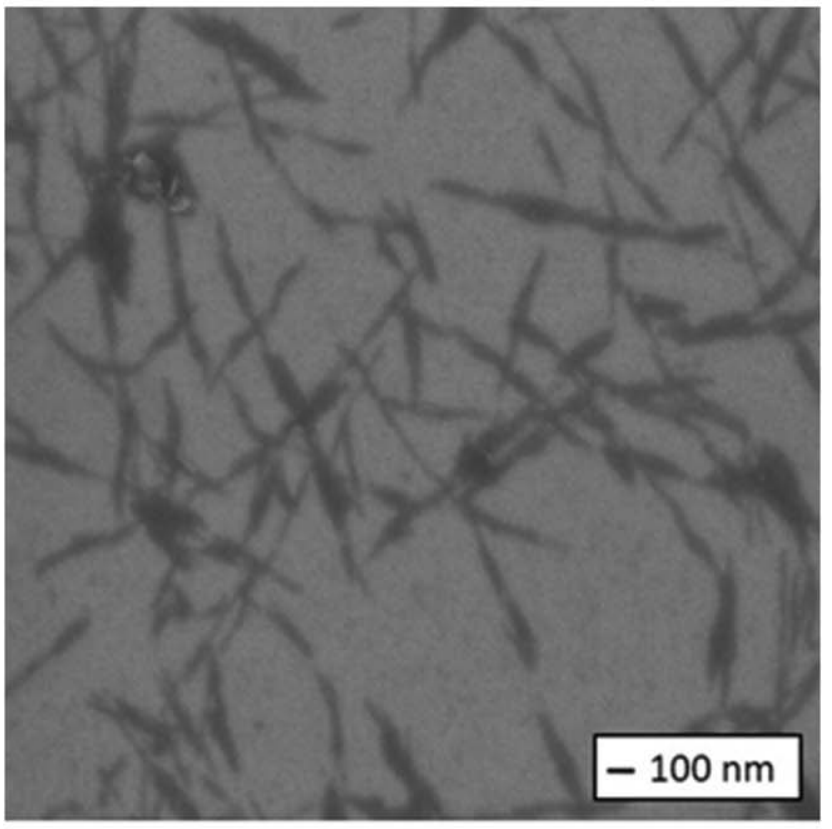

(b)

Figure 5. FEG-SEM micrographs of the CNF obtained after enzymatic hydrolysis at $50^{\circ} \mathrm{C}$ using $20 \%$ solids loading and $10 \mathrm{mg}$ protein $/ \mathrm{g}$ enzyme loading, (a) after $24 \mathrm{~h}$, and (b) after $72 \mathrm{~h}$ with reduction of the hydrolysis temperature to $35^{\circ} \mathrm{C}$.

$72 \mathrm{~h}$ of reaction. After $8 \mathrm{~h}$ of alcoholic fermentation, glucose was consumed to a concentration of $7.3 \mathrm{~g} / \mathrm{L}$, producing $62.1 \mathrm{~g} / \mathrm{L}$ of ethanol (Figure 4 ). The ethanol yield was $95.5 \%$ and productivity (Q) was $7.8 \mathrm{~g} / \mathrm{L} . \mathrm{h}$. After $10 \mathrm{~h}$, the glucose concentration was below $1 \mathrm{~g} / \mathrm{L}$ and the ethanol concentration was $67.9 \mathrm{~g} / \mathrm{L}$. Elsewhere, ${ }^{28}$ reported a $91.6 \%$ ethanol yield from bleached kraft eucalyptus pulp, which was attributed to the presence of glucose and absence of xylose. The presence of inhibitors derived from the degradation of hemicellulose or lignin interferes negatively in alcoholic fermentation processes. ${ }^{60}$ In this work, the low concentrations of hemicellulose 


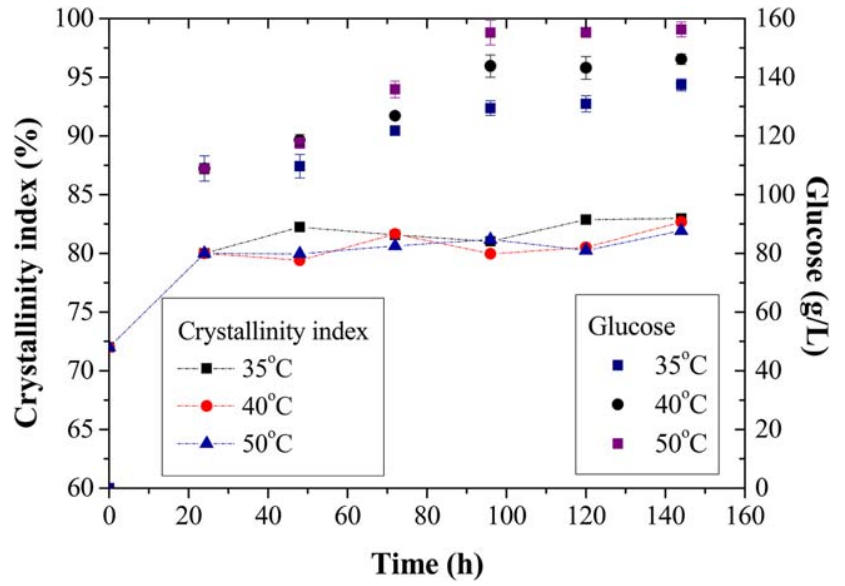

Figure 6. Influence of temperature on the crystallinity index profile and the glucose concentration, as a function of time up to $144 \mathrm{~h}$, for hydrolysis at $35^{\circ} \mathrm{C}$ (squares), $40^{\circ} \mathrm{C}$ (circles), and $50^{\circ} \mathrm{C}$ (triangles), using $20 \%$ solids loading and $10 \mathrm{mg}$ protein/g enzyme loading.

and lignin in the raw material could have contributed to good fermentation performance, showing the viability of producing ethanol with the sugar released from eucalyptus pulp under the experimental conditions selected for this integrated process.

It can be observed in Figure 4 that glucose consumption rate decreased after $2 \mathrm{~h}$ of fermentation. This phenomenon is possibly explained by the inhibitory effect of the ethanol accumulation in the media on cell growth rate and yeast performance. It has been previously reported that ethanol concentrations above $40 \mathrm{~g} / \mathrm{L}$ decreases cell growth. ${ }^{53}$ Figure 4 also shows that ethanol production reached a plateau after $6 \mathrm{~h}$ of fermentation while the glucose was still being consumed. This phenomenon is possibly related to the production of secondary metabolites, such as glycerol. Therefore, monitoring of the different metabolites released over time as well as the cell concentration profile would contribute to a better understanding of the process to further improve the alcoholic fermentation efficiency.

\section{CNC from the solid residues of enzymatic hydrolysis}

The residual solids remaining after $24 \mathrm{~h}$ for all the enzymatic hydrolysis reactions described in Table 1 were characterized by FEG-SEM. After $24 \mathrm{~h}$ of reaction, CNF structures similar to those illustrated in Figure 5 were observed, for all the experimental conditions evaluated (Table 1). To investigate the possibility of obtaining $\mathrm{CNC}$ directly after the enzymatic hydrolysis reaction, a strategy was proposed for reducing the temperature and extending the reaction time. Therefore, after $24 \mathrm{~h}$ of hydrolysis at $50^{\circ} \mathrm{C}$, the temperature was reduced to 35 or $40^{\circ} \mathrm{C}$ and the reaction was monitored during $144 \mathrm{~h}$. Crystallinity index values and glucose concentrations were determined for all the conditions studied (Figure 6).

The crystallinity index is an important parameter that describes the amorphous and crystalline fractions of the material. Figure 6 shows an increase in the crystallinity index of the material from 72 to $80 \%$ in $24 \mathrm{~h}$ of reaction at $50^{\circ} \mathrm{C}$. However, during the remainder of the hydrolysis reaction, there was only a slight change in the crystallinity index, which increased from 80 to $83 \%$. This showed that the crystallinity index was not significantly influenced either by the

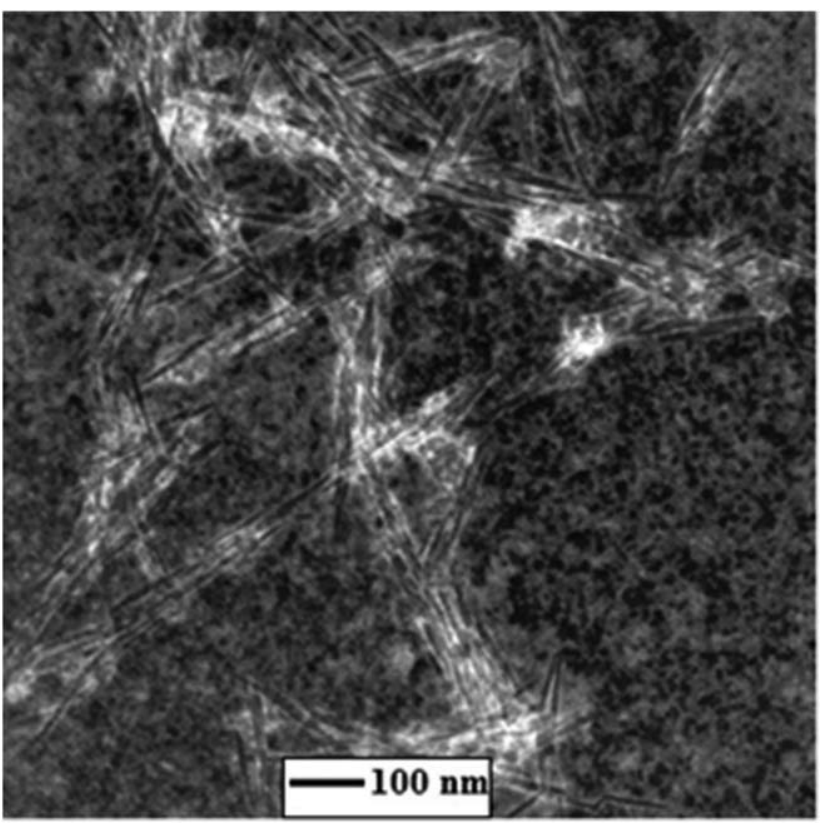

Figure 7. STEM micrograph of CNC obtained after hydrolysis of the eucalyptus pulp at $35^{\circ} \mathrm{C}$ for $144 \mathrm{~h}$, using solids loading of $20 \%$ and enzyme loading of $10 \mathrm{mg}$ protein/g.

temperature used or by an extended reaction time. Nevertheless, the glucose concentration increased from 110 to $156 \mathrm{~g} /$ $\mathrm{L}$ after $144 \mathrm{~h}$ at $50^{\circ} \mathrm{C}$. A reduced efficiency of the enzymatic complex was indicated by the lower glucose concentration obtained when the temperature was reduced (Figure 6). When the temperature was reduced to 35 and $40^{\circ} \mathrm{C}$, the glucose concentrations obtained after $144 \mathrm{~h}$ were 137 and $146 \mathrm{~g} / \mathrm{L}$, respectively, while the crystallinity index values remained close to $83 \%$.

An increase of $24 \%$ in crystallinity after $48 \mathrm{~h}$ of hydrolysis of eucalyptus cellulose pulp was reported previously, ${ }^{28}$ although the crystallinity remained stable as the reaction time was extended up to $72 \mathrm{~h}$. The strategy of temperature reduction was adopted to avoid the degradation of crystalline cellulose due to the extended reaction time. The optimum temperature of the cellulase enzymes is around $50^{\circ} \mathrm{C},{ }^{61}$ so it is reasonable to assume that the reaction rate was lowered by reducing the temperature, with a decrease in the sugars released when the temperature was changed from 50 to $35^{\circ} \mathrm{C}$. An additional point is that there is an economic advantage of using a lower temperature, due to the lower expenditure of energy.

\section{Morphology of the CNC}

The residual solid materials obtained after the enzymatic hydrolysis of the eucalyptus pulp under the optimized conditions (SL 20\%, EL $10 \mathrm{mg}$ protein/g, and reduction of the temperature from 50 to $35^{\circ} \mathrm{C}$ after $24 \mathrm{~h}$ and keeping it constant up to $144 \mathrm{~h}$ ) were evaluated by FEG-SEM and STEM (Figure 7). For all the samples, a rod-like appearance typical of nanocellulose was observed, as shown in Figure 5 for the periods of 24 and $72 \mathrm{~h}$. However, after $144 \mathrm{~h}$ of reaction, $\mathrm{CNC}$ structures with rod-like and needle-like shapes were obtained (Figure 7).

The effect of hydrolysis time on the diameter of the structures is illustrated in Figure 8. The diameter and length 


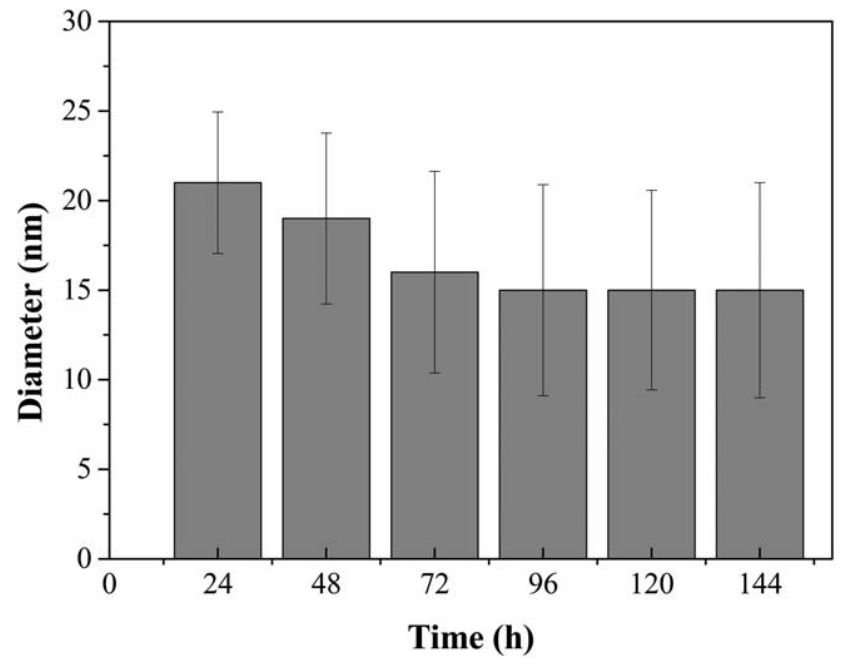

Figure 8. Profile of the diameter of nanocellulose obtained after enzymatic hydrolysis for periods between $24 \mathrm{~h}$ (hydrolysis at $50^{\circ} \mathrm{C}$ ) and $144 \mathrm{~h}$ (hydrolysis at $35^{\circ} \mathrm{C}$ ), using $20 \%$ solids loading and $10 \mathrm{mg}$ protein $/ \mathrm{g}$ enzyme loading.

values were determined using Image Pro-Plus software, with observation of around 100 structures. The values refer to the average of these 100 individual measurements, which were estimated using digital image processing tools. Before undergoing the enzymatic hydrolysis process, the eucalyptus cellulose pulp diameter was $16 \pm 4 \mu \mathrm{m}$. The hydrolysis process resulted in a significant reduction in diameter, with thin $\mathrm{CNF}$ structures $21 \pm 3 \mathrm{~nm}$ in diameter after $24 \mathrm{~h}$ and CNC structures $15 \pm 6 \mathrm{~nm}$ in diameter after $144 \mathrm{~h}$. The diameter changes of cellulosic nanostructures caused by enzymatic and mechanical processes were described by Campos et al. $^{46}$, who showed that the use of enzymatic hydrolysis after an ultrasound process reduced the nanofiber diameter to less than $30 \mathrm{~nm}$ and decreased the sonication time required.

The CNC obtained here had a length (L) of around 216 $\mathrm{nm} \pm 86 \mathrm{~nm}$, diameter (D) of $15 \mathrm{~nm} \pm 6 \mathrm{~nm}$, and aspect ratio of 15 . These features were in agreement with the characteristics of CNC reported by, ${ }^{62}$ who described $\mathrm{CNC}$ with lengths in the range 100-250 $\mathrm{nm}$ and diameters between 8 and $70 \mathrm{~nm}$ for $\mathrm{CNC}$ from vegetal sources. Tonoli et al. ${ }^{63}$ reported different values for $\mathrm{CNC}$ from recycled cellulose pulp, with fiber lengths from 100 to $1.8 \mu \mathrm{m}$ and diameters from 30 to $80 \mathrm{~nm}$, after 50 and $60 \mathrm{~min}$ of enzymatic hydrolysis. Previous studies of nanocellulose obtained from eucalyptus pulp using enzymatic hydrolysis coupled with mechanical treatment (microfluidizer) resulted in structures with length of $500 \mathrm{~nm}$ and diameter of $20 \mathrm{~nm}^{28}$ Teixeira et al. ${ }^{31}$ obtained $\mathrm{CNC}$ with length of $500 \mathrm{~nm}$ and diameter of $6 \mathrm{~nm}$ after $72 \mathrm{~h}$ of enzymatic reaction combined with a wet disk milling step, while Cui et al. ${ }^{48}$ used ultrasonicassisted enzymatic hydrolysis to produce $\mathrm{CNC}$ with values similar to those for the eucalyptus pulp cellulose $(L=100$ $500 \mathrm{~nm} ; D=5-8 \mathrm{~nm}$ ).

This wide range of values could be attributed to the different operational conditions used as well as the different enzymatic cocktails. An enzymatic complex rich in endoglucanases will facilitate removal of the amorphous cellulose, while use of a complex containing exoglucanases enables the degradation of crystalline cellulose. ${ }^{61}$ An increase in the enzymatic hydrolysis reaction time may cause

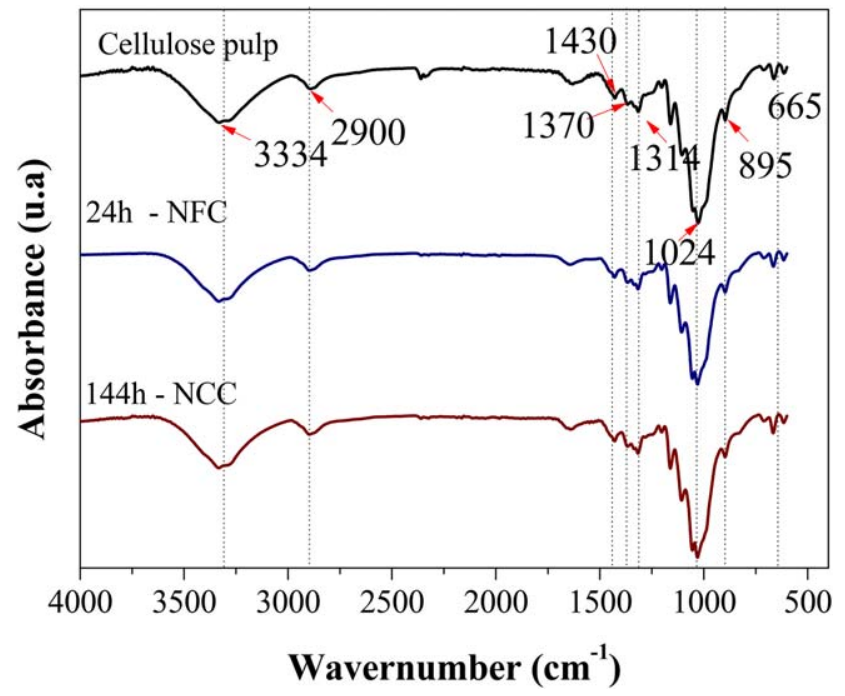

Figure 9. FTIR spectra for the original eucalyptus pulp, CNF (after hydrolysis for $24 \mathrm{~h}$ at $50^{\circ} \mathrm{C}$ ), and CNC (after hydrolysis for $144 \mathrm{~h}$ at $35^{\circ} \mathrm{C}$ ), using $20 \%$ solids loading and $10 \mathrm{mg}$ protein/g enzyme loading.

the CNC length to decrease due to fragmentation of the crystalline cellulose fraction, releasing amorphous material present in the cellulosic structure.

Previous works reporting CNC production by acid methods applied to sources of cellulose including eucalyptus showed the advantage of the enzymatic method and found similar ranges of length and diameter, with $L=175-142 \mathrm{~nm}$ and $D=11-15 \mathrm{~nm}$ for eucalyptus cellulose, ${ }^{63} L=100$ $300 \mathrm{~nm}$ and $D=3-10 \mathrm{~nm}$ for waste paper, ${ }^{64}$ and $L=500 \mathrm{~nm}$ and $D=1-9 \mathrm{~nm}$ for wood. ${ }^{65}$ However, it is important to emphasize that obtaining CNC using enzymatic hydrolysis alone is innovative. This finding also opens opportunities for using enzymes with different specificities for obtaining $\mathrm{CNC}$ with different properties and, consequently, suitable for different applications.

\section{FTIR analysis}

Figure 9 shows the FTIR spectra of the original eucalyptus cellulose pulp, CNF after hydrolysis for $24 \mathrm{~h}$ at $50^{\circ} \mathrm{C}$, and $\mathrm{CNC}$ after $144 \mathrm{~h}$ at $35^{\circ} \mathrm{C}$. The FTIR spectra were similar for all the samples evaluated. A band at approximately $3340 \mathrm{~cm}^{-1}$ corresponded to stretching vibration of $\mathrm{O}-\mathrm{H}$, and a $\mathrm{C}-\mathrm{H}$ band at $2900 \mathrm{~cm}^{-1}$ could be attributed to the aliphatic structures in lignin, cellulose, and hemicelluloses. ${ }^{66,67}$ The amorphous cellulose pulp showed bands corresponding to the deformation and stretching of cellulose $\mathrm{COC}, \mathrm{CCO}$, and $\mathrm{CCH}$ bonds at around $895 \mathrm{~cm}^{-1} \cdot{ }^{6}$ In the subsequent samples obtained after the enzymatic hydrolysis reactions, these peaks decreased and shifted to $898 \mathrm{~cm}^{-1}$. This band reflected the presence of amorphous cellulose that could be processed into glucose by the action of endoglucanases and $\beta$-glucosidases.

A band at around $665 \mathrm{~cm}^{-1}$ was assigned to out-of-plane $\mathrm{C}-\mathrm{OH}$ groups characteristic of cellulose pulp. ${ }^{68}$ Asymmetric deformation of $\mathrm{CH}$ and $\mathrm{COH}$ groups at $1430 \mathrm{~cm}^{-1}$ and angular symmetrical $\mathrm{CH}_{2}$ groups at $1315 \mathrm{~cm}^{-1}$ and $1370 \mathrm{~cm}^{-1}$ were associated with crystalline cellulose. ${ }^{66}$ The presence of bands between 1315 and $1430 \mathrm{~cm}^{-1}$ in all the spectra showed that there was no degradation of crystalline cellulose by the enzymes. 


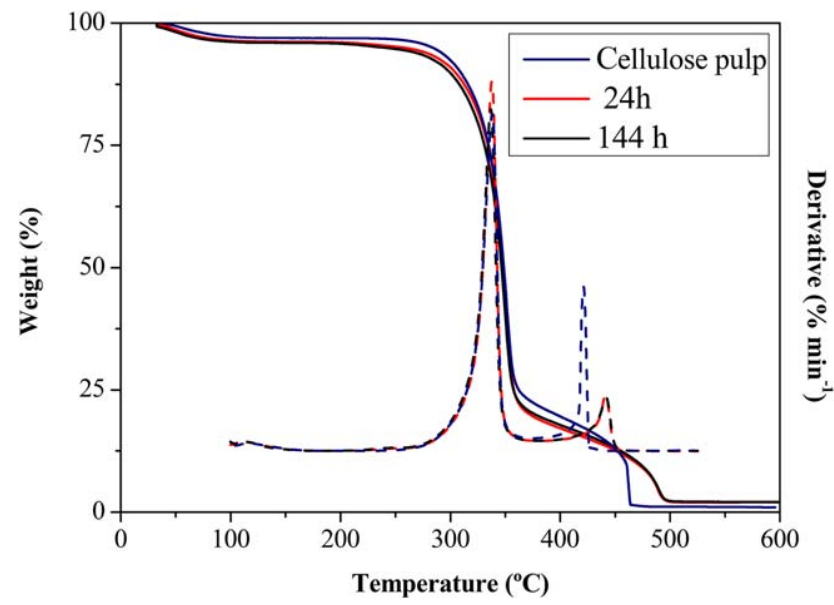

Figure 10. TGA and DTG curves for the original eucalyptus pulp, CNF (after hydrolysis for $24 \mathrm{~h}$ at $50^{\circ} \mathrm{C}$ ), and CNC (after hydrolysis for $144 \mathrm{~h}$ at $35^{\circ} \mathrm{C}$ ), using $20 \%$ solids loading and $10 \mathrm{mg}$ protein $/ \mathrm{g}$ enzyme loading.

The presence of absorbed water was indicated by a band at $1630 \mathrm{~cm}^{-1}$. Peaks between 1023 and $1076 \mathrm{~cm}^{-1}$ corresponded to $\mathrm{C}-\mathrm{C}$ bonds present in the pyranose rings and structures associated with hemicellulose. Additional characteristic hemicellulose and cellulose bands were present at 2900 and $3334 \mathrm{~cm}^{-1}$, and from 1105 to $1160 \mathrm{~cm}^{-1}$, corresponding to the symmetrical stretching of $\mathrm{C}-\mathrm{H}, \mathrm{OH}$, and $\mathrm{C}-$ $\mathrm{O}-\mathrm{C}$ bonds of the glucose rings. ${ }^{68}$

\section{Thermal stability}

The thermal stabilities of the eucalyptus cellulose pulp, $\mathrm{CNF}$, and CNC samples were investigated using the thermogravimetric method (Figure 10). The complexity of cellulose degradation is due to the large number of steps of the parallel and consecutive reactions, including the dehydration, decarboxylation, and decarbonylation of anhydroglucose units. $^{69,70}$ The TGA and DTG results showed a small initial mass loss between 50 and $150^{\circ} \mathrm{C}$, corresponding to the evaporation of absorbed water. The temperature for initiation of thermal degradation was characteristic of the main lignocellulosic constituents (cellulose, hemicellulose, and lignin). The degradation of cellulose occurred at $331^{\circ} \mathrm{C}$ for the original eucalyptus cellulose pulp, $323^{\circ} \mathrm{C}$ for $\mathrm{CNF}(24 \mathrm{~h})$, and $325^{\circ} \mathrm{C}$ for CNC (144 h). The decomposition of hemicellulose occurred between 240 and $310^{\circ} \mathrm{C}$, and lignin degraded in a wide temperature interval between 200 and $550^{\circ} \mathrm{C}$.

The third DTG thermal decomposition peak occurred at $440^{\circ} \mathrm{C}$ for the original material and at $420^{\circ} \mathrm{C}$ for $\mathrm{CNF}(24 \mathrm{~h})$ and $\mathrm{CNC}(144 \mathrm{~h})$. The lower temperature of this thermal event for $\mathrm{CNF}$ and $\mathrm{CNC}$ could be explained by the presence of smaller amounts of lignin and hemicellulose, due to the presence of accessory enzymes in the commercial complex used, which were responsible for reducing the concentrations of these compounds in the materials. Previous studies have found that $\mathrm{CNC}$ obtained by enzymatic hydrolysis exhibited superior thermal stability, compared to CNC obtained by chemical hydrolysis with sulfuric acid. The CNC obtained by enzymatic hydrolysis began to degrade at $359^{\circ} \mathrm{C}$, while degradation of the CNC obtained using sulfuric acid started at $184^{\circ} \mathrm{C}$. The lower thermal stability of $\mathrm{CNC}$ obtained by chemical reaction could be explained by the presence of sulfate groups on the cellulose surface. ${ }^{71}$ The degradation temperature imposes a limit on the use of $\mathrm{CNC}$, and a high temperature for the initiation of thermal degradation extends the range of applications of this material. ${ }^{20}$ Thermal stability is an important property for CNC used in thermoplastic polymers whose manufacture requires a high temperature (typically above $\left.200^{\circ} \mathrm{C}\right){ }^{67}$

The CNF and CNC obtained here using enzymatic hydrolysis presented superior thermal stability, compared to materials obtained by means of chemical hydrolysis reactions. These materials can be of potential interest for a range of applications relevant to the fields of material science and biomedical engineering. In fact, nanocellulose has been considered as the most attractive renewable material for advanced applications due to its excellent mechanical properties, good biocompatibility, tailorable surface chemistry, and interesting optical properties. ${ }^{72}$ Industrial applications of nanocellulose include devices for use in biomedicine, ${ }^{21}$ packaging, ${ }^{22}$ and mechanical reinforcement of matrices, ${ }^{23}$ enzyme immobilization, ${ }^{24}$ among other applications. ${ }^{25,72}$

In overall, our findings showed the viability for the integrated production of $\mathrm{CNC}$ and ethanol with the sugar released from the enzymatic hydrolysis of eucalyptus pulp. The production of CNC in an integrated biorefinery with ethanol could have a positive economic impact in this process, as it has been previously demonstrated for crop residues such as wheat straw. ${ }^{73}$

\section{CONCLUSION}

In this work, an approach using an exclusively biochemical pathway was successfully developed for the integrated production of nanocellulose together with sugar at a sufficiently high concentration for ethanol production. The use of experimental design methodology and the desirability function as statistical tools enabled selection of an optimum condition for obtaining CNC and glucose, using a high SL and a low enzyme loading. Such conditions are required to ensure economic viability of the integrated process. Alcoholic fermentation of the sugars released in the hydrolysis resulted in a process efficiency of over $95 \%$. The use of a temperature reduction strategy for the enzymatic hydrolysis step resulted in the formation of CNC. Crystallinity index analysis of this nanomaterial revealed an increase of its crystallinity, which together with physical-chemical-morphological analysis confirmed the presence of $\mathrm{CNC}$. The nanocellulose structures presented high thermal stability and elongated and thin shapes with an aspect ratio $(L / D)$ typical of CNC. These features are important for the use of these substances to reinforce polymeric materials. The findings demonstrate that use of the enzymatic hydrolysis approach to obtain nanometric materials provides a green and environmentally favorable alternative to conventional chemical procedures. The integration of nanocellulose and ethanol production exclusively by a biochemical pathway contributes to the future implementation of forest biorefineries and diversification of the pulp and paper sector, in an approach that is coherent with the principles of green chemistry.

\section{Conflicts of Interest}

The authors declare that there are no conflicts of interest concerning the publication of this article. 


\section{Acknowledgments}

The authors would like to thank Embrapa, MCTI/SISNANO, CNPq, CAPES, and FAPESP (Process 2016/106368) (all from Brazil) for their financial support.

\section{Literature Cited}

1. Moshkelani M, Marinova M, Perrier M, Paris J. The forest biorefinery and its implementation in the pulp and paper industry: energy overview. Appl Thermal Eng. 2013;50:1427-1436.

2. Sheldon RA. Green and sustainable manufacture of chemicals from biomass: state of the art. Green Chem. 2014;16:950-963.

3. Kamm B, Kamm M. Principles of biorefineries. Appl Microbiol Biotechnol. 2004;64:137-145.

4. Mohan SV, Nikhil GN, Chiranjeevi P, Reddy CN, Rohit MV, Kumar AN, Sarkar O. Waste biorefinery models towards sustainable circular bioeconomy: critical review and future perspectives. Bioresour Technol. 2016;215:2-12.

5. Rafione T, Marinova M, Montastruc L, Paris J. The green integrated forest biorefinery: an innovative concept for the pulp and paper mills. Appl Thermal Eng. 2014;73:74-81.

6. Brinchi L, Cotana F, Fortunati E, Kenny JM. Production of nanocrystalline cellulose from lignocellulosic biomass: technology and applications. Carbohyd Polym. 2013;94:154-169.

7. Mariano AP. How Brazilian pulp mills will look in the future? O Papel. 2015;76:51-66.

8. Van Heiningen A. Converting a kraft pulp mill into an integrated forest biorefinery. Pulp Paper Canada 2006;107:38-43.

9. Hytoenen E, Stuart PR. Integrating bioethanol production into an integrated kraft pulp and paper mill: techno-economic assessment. Pulp Paper Canada 2009;110:25-32.

10. Frederick WJ, Jr., Lien SJ, Courchene CE, DeMartini NA, Ragauskas AJ, Iisa K. Co-production of ethanol and cellulose fiber from Southern Pine: A technical and economic assessment. Biomass Bioenergy 2008;32:1293-1302.

11. Mu DY, Seager T, Rao PS, Zhao F. Comparative life cycle assessment of lignocellulosic ethanol production: biochemical versus thermochemical conversion. Environ Manag. 2010;46: $565-578$.

12. Lopes MSG. Engineering biological systems toward a sustainable bioeconomy. J Ind Microbiol Biotechnol. 2015;42:813-838.

13. Heux S, Meynial-Salles I, O'Donohue MJ, Dumon C. White biotechnology: state of the art strategies for the development of biocatalysts for biorefining. Biotechnol Adv. 2015;33:1653-1670.

14. Koppram R, Tomas-Pejo E, Xiros C, Olsson L. Lignocellulosic ethanol production at high-gravity: challenges and perspectives. Trend Biotechnol. 2014;32:46-53.

15. Zeng MJ, Ximenes E, Ladisch MR, Mosier NS, Vermerris W, Huang CP, Sherman DM. Tissue-specific biomass recalcitrance in corn stover pretreated with liquid hot-water: enzymatic hydrolysis (part 1). Biotechnol Bioeng. 2012;109:390-397.

16. Pereira SC, Maehara L, Machado CMM, Farinas CS. Physicalchemical-morphological characterization of the whole sugarcane lignocellulosic biomass used for $2 \mathrm{G}$ ethanol production by spectroscopy and microscopy techniques. Renew Energy 2016;87: 607-617.

17. Pereira SC, Maehara L, Machado CMM, Farinas CS. $2 \mathrm{G}$ ethanol from the whole sugarcane lignocellulosic biomass. Biotechnol Biofuel. 2015;8:16.

18. Zhang Y, Lynd L. Toward an aggregated understanding of enzymatic hydrolysis of cellulose: noncomplexed cellulase systems. Biotechnol Bioeng. 2004;88:797-824.

19. Siqueira G, Bras J, Dufresne A. Cellulose Whiskers versus microfibrils: influence of the nature of the nanoparticle and its surface functionalization on the thermal and mechanical properties of nanocomposites. Biomacromolecules 2009;10:425-432.

20. Dufresne A. Nanocellulose: a new ageless bionanomaterial. Mater Today 2013;16:220-227.

21. Lin N, Dufresne A. Nanocellulose in biomedicine: current status and future prospect. Europ Polym J. 2014;59:302-325.

22. Azeredo H. M C d. Nanocomposites for food packaging applications. Food Res Int. 2009;42:1240-1253.
23. Pasquini D, Teixeira E. d M, da Silva Curvelo AA, Belgacem MN, Dufresne A. Extraction of cellulose whiskers from cassava bagasse and their applications as reinforcing agent in natural rubber. Ind Crop Product. 2010;32:486-490.

24. Kim TG, Park TG. Surface functionalized electrospun biodegradable nanofibers for immobilization of bioactive molecules. Biotechnol Prog. 2006;22:1108-1113.

25. Habibi Y, Lucia LA, Rojas OJ. Cellulose nanocrystals: chemistry, self-assembly, and applications. Chem Rev. 2010;110:34793500 .

26. Teixeira EDM, Bondancia TJ, Ricardo Teodoro KB, Correa AC, Marconcini JM, Caparelli Mattoso LH. Sugarcane bagasse whiskers: extraction and characterizations. Ind Crop Product. 2011;33:63-66.

27. Teodoro KBR, Teixeira ED, Correa AC, de Campos A, Marconcini JM, Mattoso LHC. Whiskers from sisal fibers obtained under different acid hydrolysis conditions: effect of time and temperature of extraction. Polimeros-Ciencia E Tecnologia 2011;21:280-285.

28. Zhu JY, Sabo R, Luo XL. Integrated production of nanofibrillated cellulose and cellulosic biofuel (ethanol) by enzymatic fractionation of wood fibers. Green Chem. 2011;13:1339-1344.

29. Oksman K, Etang JA, Mathew AP, Jonoobi M. Cellulose nanowhiskers separated from a bio-residue from wood bioethanol production. Biomass Bioenergy 2011;35:146-152.

30. Le Normand M, Moriana R, Ek M. Isolation and characterization of cellulose nanocrystals from spruce bark in a biorefinery perspective. Carbohyd Polym. 2014;111:979-987.

31. Teixeira RSS, da Silva AS, Jang JH, Kim HW, Ishikawa K, Endo T, Lee SH, Bon EPS. Combining biomass wet disk milling and endoglucanase/beta-glucosidase hydrolysis for the production of cellulose nanocrystals. Carbohyd Polym. 2015;128: 75-81.

32. Mathew AP, Oksman K, Karim Z, Liu P, Khan SA, Naseri N. Process scale up and characterization of wood cellulose nanocrystals hydrolysed using bioethanol pilot plant. Ind Crop Product. 2014;58:212-219.

33. Tsukamoto J, Duran N, Tasic L. Nanocellulose and bioethanol production from orange waste using isolated microorganisms. J Brazil Chem Soc. 2013;24:1537-1543.

34. Camargo LA, Pereira SC, Correa AC, Farinas CS, Marconcini JM, Mattoso LHC. Feasibility of manufacturing cellulose nanocrystals from the solid residues of second-generation ethanol production from sugarcane bagasse. Bioenergy Res. 2016;9:894906.

35. Pirani S, Hashaikeh R. Nanocrystalline cellulose extraction process and utilization of the byproduct for biofuels production. Carbohyd Polym. 2013;93:357-363.

36. Cannella D, Jorgensen H. Do new cellulolytic enzyme preparations affect the industrial strategies for high solids lignocellulosic ethanol production? Biotechnol Bioeng. 2014;111:59-68.

37. Kristensen JB, Felby C, Jorgensen H. Yield-determining factors in high-solids enzymatic hydrolysis of lignocellulose. Biotechnol Biofuel. 2009;2:11.

38. Roberts KM, Lavenson DM, Tozzi EJ, McCarthy MJ, Jeoh T. The effects of water interactions in cellulose suspensions on mass transfer and saccharification efficiency at high solids loadings. Cellulose 2011;18:759-773.

39. Hodge DB, Karim MN, Schell DJ, McMillan JD. Soluble and insoluble solids contributions to high-solids enzymatic hydrolysis of lignocellulose. Bioresour Technol. 2008;99:8940-8948.

40. Hsieh C-WC, Cannella D, Jorgensen H, Felby C, Thygesen LG. Cellulase inhibition by high concentrations of monosaccharides. J Agri Food Chem. 2014;62:3800-3805.

41. Xiao ZZ, Zhang X, Gregg DJ, Saddler JN. Effects of sugar inhibition on cellulases and beta-glucosidase during enzymatic hydrolysis of softwood substrates. Appl Biochem Biotechnol. 2004; 113:1115-1126.

42. Ko JK, Ximenes E, Kim Y, Ladisch MR. Adsorption of enzyme onto lignins of liquid hot water pretreated hardwoods. Biotechnol Bioeng. 2015;112:447-456.

43. Jorgensen H, Vibe-Pedersen J, Larsen J, Felby C. Liquefaction of lignocellulose at high-solids concentrations. Biotechnol Bioeng. 2007;96:862-870. 
44. Johnson E. Integrated enzyme production lowers the cost of cellulosic ethanol. Biofuel Bioproduct Biorefin Biofpr. 2016;10: $164-174$.

45. Klein-Marcuschamer D, Oleskowicz-Popiel P, Simmons BA, Blanch HW. The challenge of enzyme cost in the production of lignocellulosic biofuels. Biotechnol Bioeng. 2012;109:1083-1087.

46. Campos A, Correa AC, Cannella D, Teixeira EDM, Marconcini JM, Dufresne A, Mattoso LHC, Cassland P, Sanadi AR. Obtaining nanofibers from curaua and sugarcane bagasse fibers using enzymatic hydrolysis followed by sonication. Cellulose 2013;20: 1491-1500.

47. Woehl MA, Canestraro CD, Mikowski A, Sierakowski MR, Ramos LP, Wypych F. Bionanocomposites of thermoplastic starch reinforced with bacterial cellulose nanofibres: effect of enzymatic treatment on mechanical properties. Carbohyd Polym. 2010;80:866-873.

48. Cui S, Zhang S, Ge S, Xiong L, Sun Q. Green preparation and characterization of size-controlled nanocrystalline cellulose via ultrasonic-assisted enzymatic hydrolysis. Ind Crop Product. 2016;83:346-352.

49. Sluiter A, Hames B, Ruiz R, Scarlata C, Sluiter J, Templeton D, Crocker D. Determination of Structural Carbohydrates and Lignin in Biomass; NREL-National Renewable Energy Laboratory. 2012. http://www.nrel.gov/bioenergy/biomass-compositional-analysis.html

50. Ghose TK. Mesurement of cellulase activities. Pure Appl Chem. 1987;59:257-268.

51. Bradford MM. Rapid and sensitive method for quantitation of microgram quantities of protein utilizing principle of quantities of protein utilizing principle of protein-dye binding. Anal Biochem. 1976;72:248-254.

52. Meyers RH, Montgomery DC, Anderson-Cook CM. Response Surface Methodology: Process and Product Optimization Using Designed Experiments 3rd ed, New York: John Wiley \& Sons, Inc. 2009.

53. Sonego JLS, Lemos DA, Rodriguez GY, Cruz AJG, Badino AC. Extractive batch fermentation with $\mathrm{CO}_{2}$ stripping for ethanol production in a bubble column bioreactor: experimental and modeling. Energy Fuel. 2014;28:7552-7559.

54. Segal L, Creely JJ, Maartin AE, Conrad CM. An empirical method for estimating the degree of cristallinity of native cellulose using the X-Ray diffractometer. Text Res J. 1959;29:786-794.

55. Ximenes E, Kim Y, Mosier N, Dien B, Ladisch M. Inhibition of cellulases by phenols. Enzyme Microbial Technol. 2010;46:170176.

56. Zhang X, Qin W, Paice MG, Saddler JN. High consistency enzymatic hydrolysis of hardwood substrates. Bioresour Technol. 2009;100:5890-5897.

57. Jorgensen H, Kristensen JB, Felby C. Enzymatic conversion of lignocellulose into fermentable sugars: challenges and opportunities. Biofuel Bioproduct Biorefin Biofpr. 2007;1:119-134.

58. Vasquez MP, da Silva JNC, de Souza MB, Pereira N. Enzymatic hydrolysis optimization to ethanol production by simultaneous saccharification and fermentation. Appl Biochem Biotechnol. 2007; 137:141-153.
59. Bezerra MA, Santelli RE, Oliveira EP, Villar LS, Escaleira LA. Response surface methodology (RSM) as a tool for optimization in analytical chemistry. Talanta 2008;76:965-977.

60. Palmqvist E, Hahn-Hagerdal B. Fermentation of lignocellulosic hydrolysates. II: inhibitors and mechanisms of inhibition. Bioresour Technol. 2000;74:25-33.

61. Lynd L, Weimer P, van Zyl W, Pretorius I. Microbial cellulose utilization: fundamentals and biotechnology. Microbiol Mol Biol Rev. 2002;66:506-577.

62. Klemm D, Heublein B, Fink HP, Bohn A. Cellulose: fascinating biopolymer and sustainable raw material. Angewandte Chemie International Edition 2005;44:3358-3393.

63. Tonoli GHD, Teixeira EM, Correa AC, Marconcini JM, Caixeta LA, Pereira-da-Silva MA, Mattoso LHC. Cellulose micro/nanofibres from Eucalyptus kraft pulp: preparation and properties. Carbohyd Polym. 2012;89:80-88.

64. Danial WH, Majid ZA, Muhid MNM, Triwahyono S, Bakar MB, Ramli Z. The reuse of wastepaper for the extraction of cellulose nanocrystals. Carbohyd Polym. 2015;118:165-169.

65. Li YN, Liu YZ, Chen WS, Wang QW, Liu YX, Li J, Yu HP. Facile extraction of cellulose nanocrystals from wood using ethanol and peroxide solvothermal pretreatment followed by ultrasonic nanofibrillation. Green Chem. 2016;18:1010-1018.

66. Sun XF, Xu F, Sun RC, Fowler P, Baird MS. Characteristics of degraded cellulose obtained from steam-exploded wheat straw. Carbohyd Res. 2005;340:97-106.

67. Alemdar A, Sain M. Isolation and characterization of nanofibers from agricultural residues-wheat straw and soy hulls. Bioresour Technol. 2008;99:1664-1671.

68. Dai D, Fan M. Investigation of the dislocation of natural fibres by Fourier-transform infrared spectroscopy. Vibrat Spectroscopy 2011;55:300-306.

69. Abidi N, Hequet E, Ethridge D. Thermogravimetric analysis of cotton fibers: relationships with maturity and fineness. $J$ Appl Polym Sci. 2007;103:3476-3482.

70. Corradini E, Teixeira EM, Paladin PD, Agnelli JA, Silva ORRF, Mattoso LHC. Thermal stability and degradation kinetic study of white and colored cotton fibers by thermogravimetric analysis. J Therm Anal Calorimet. 2009;97:415-419.

71. George J, Ramana KV, Bawa AS. Siddaramaiah Bacterial cellulose nanocrystals exhibiting high thermal stability and their polymer nanocomposites. Int J Biol Macromol. 2011;48:50-57.

72. Abitbol T, Rivkin A, Cao YF, Nevo Y, Abraham E, BenShalom T, Lapidot S, Shoseyov O. Nanocellulose, a tiny fiber with huge applications. Curr Opin Biotechnol. 2016;39:76-88.

73. Leistritz FL, Senechal DM, Stowers MD, McDonald WF, Saffron CM, Hodur NM. Preliminary feasibility analysis for an integrated biomaterials and ethanol biorefinery using wheat straw feedstock. In Agribusiness \& Applied Economics Report No. 590, 2006:1-48

Manuscript received Jan. 3, 2017, and revision received Mar. 27, 2017. 